\title{
Pengaruh Moral Pajak, Sanksi Pajak, dan Kebijakan Pengampunan Pajak Terhadap Kepatuhan Pajak Wajib Pajak Orang Pribadi
}

\author{
Sriniyati* \\ *Akademi Akuntansi YKPN Yogyakarta \\ Jl. Gagak Rimang no. 2-4, Gondokusuman, Yogyakarta \\ E-mail: rsriniyati@gmail.com
}

\begin{abstract}
Abstrak
Penelitian ini bertujuan untuk menguji pengaruh moral pajak, sanksi pajak, dan kebijakan pengampunan pajak terhadap kepatuhan pajak wajib pajak orang pribadi di Daerah Istimewa Yogyakarta. Variabel terikat penelitian ini adalah kepatuhan pajak wajib pajak orang pribadi. Variabel bebas terdiri atas moral pajak, sanksi pajak, dan kebijakan pengampunan pajak. Penelitian ini menggunakan variabel kontrol yang terdiri atas jenis kelamin, umur, pendidikan, serta tingkat penghasilan. Penelitian ini dilakukan dengan metode survei menggunakan kuesioner. Penelitian ini menggunakan sampel sebanyak 106 responden yang merupakan wajib pajak orang pribadi. Pengambilan sampel dilakukan dengan metode convenience. Hipotesis penelitian ini diuji dengan menggunakan regresi berganda dengan tingkat signifikansi lima persen. Hasil penelitian ini menunjukkan bahwa moral pajak dan kebijakan pengampunan pajak berpengaruh secara positif dan signifikan terhadap kepatuhan pajak wajib pajak orang pribadi. Variabel sanksi pajak dan variabel kontrol yang digunakan dalam penelitian ini tidak berpengaruh secara signfikan terhadap kepatuhan pajak wajib pajak orang pribadi di Daerah Istimewa Yogyakarta.
\end{abstract}

Kata kunci: moral pajak, sanksi pajak, pengampunan pajak

\begin{abstract}
The purpose of this research is to test the effects of tax morale, tax sanction, and tax amnesty policy towards individual taxpayer's compliance in Special Region of Yogyakarta. The dependent variable was personal taxpayer's compliance. The independent variable consists of tax morale, tax sanction, and tax amnesty policy. This research was using control variables, consists of gender, age, educational level, and income. This research was conducted with survey method using questionnaire. This research used 106 individual taxpayer's respondents. Samples of this research selected by convenience sampling. The research hypotheses was tested with linear regression in five percent significance. The result of this research indicated that tax morale and tax amnesty policy positive and significantly affected individual taxpayer's compliance. Tax sanction variable and the control variables weren't significantly affected individual taxpayer's compliances in Special Region of Yogyakarta.
\end{abstract}

Keywords: tax morale, tax sanction, tax amnesty

\section{Pendahuluan}

Penerimaan perpajakan merupakan sumber penerimaan yang memiliki porsi paling besar dalam Anggaran Pendapatan dan Belanja Negara (APBN). Pada APBN tahun 2018, penerimaan perpajakan adalah $1.618,1$ triliun rupiah atau sebesar $85,4 \%$ dari pendapatan negara. Penerimaan Negara Bukan Pajak (PNBP) hanya memiliki proporsi $14,5 \%$ serta hibah sebesar $0,1 \%$.

Dari tahun ke tahun, penerimaan pajak di Indonesia cenderung terus meningkat. Hal ini dikarenakan potensi perpajakan di Indonesia yang besar karena sebanyak 192 juta penduduk Indonesia berusia produktif (Badan Pusat Statistik, 2018). Pada kenyataannya, data yang dimiliki oleh Direktorat Jenderal Pajak (2018) menunjukkan bahwa hanya terdapat hanya 38 juta penduduk Indonesia yang terdaftar sebagai pembayar pajak dan membayar pajak mereka setiap tahun.

Salah satu indikator yang digunakan untuk mengetahui tingkat kepatuhan pajak adalah dengan menggunakan rasio pajak. Rasio pajak juga dapat digunakan untuk mengetahui potensi pajak di suatu negara. Pada tahun 2017, rasio pajak Indonesia adalah sebesar 10,82\%, dan pada tahun 2018 14 | Jurnal Akuntansi, Ekonomi dan Manajemen Bisnis | Vol. 8 No.1, July 2020, 14-23 |E-ISSN: 2548-9836 
ditargetkan sebesar 11,6\% (Nota Keuangan APBN, 2018). Rasio pajak yang dimiliki oleh Indonesia masih berada di bawah standar yang ditetapkan untuk negara-negara berkembang (lower-middle income), yang seharusnya memiliki rasio pajak $19 \%$.

Rendahnya rasio pajak di Indonesia disebabkan oleh masih banyak permasalahan terkait dengan perpajakan di Indonesia. Penelitian yang dilakukan oleh Ragimun (2014), Rahman (2017), dan Said (2017) menyebutkan bahwa kepercayaan publik terhadap otoritas pajak relatif rendah, kurangnya komitmen pemerintah untuk meningkatkan kepatuhan pajak dengan integrasi berbagai basis data dengan informasi yang relevan, sanksi pajak yang lemah, aturan dan kebijakan perpajakan yang berbelit-belit, serta masih banyaknya praktik penghindaran pajak.

Beberapa penelitian mengenai kepatuhan pajak telah banyak dilakukan sebelumnya. Penelitianpenelitian tersebut memiliki berbagai faktor yang dipandang dapat mempengaruhi kepatuhan dalam membayar pajak (Trivedi, Shehata, dan Lynn 2003; Jatmiko 2006; Mutia 2014; Rahman 2017; Suryaningtyas 2017). Penelitian mengenai dampak kebijakan perpajakan yang telah dilakukan di Indonesia, yaitu kebijakan pengampunan pajak terhadap kepatuhan pajak juga telah dilakukan oleh Wirawan dan Noviari (2017), Gerger (2012), dan Saracoglu dan Caskurlu (2011). Penelitian ini kemudian dilakukan untuk memperluas penelitian yang sebelumnya telah dilakukan. Perbedaan penelitian ini dengan penelitian sebelumnya terletak pada variabel bebas yang digunakan. Penelitian ini memperluas penelitian yang telah dilakukan oleh Saracoglu dan Caskurlu (2011) serta Wirawan dan Noviari (2017) dengan mempertimbangkan adanya variabel moral pajak.

Rendahnya rasio pajak, rendahnya kesadaran masyarakat untuk membayar pajak, serta kebijakan pemerintah yang berbelit-belit menjadi hal yang menarik untuk diteliti. Penelitian ini kemudian bertujuan untuk menguji pengaruh moral pajak, sanksi pajak, dan kebijakan pengampunan pajak terhadap kepatuhan pajak wajib pajak orang pribadi. Penelitian ini diharapkan dapat berkontribusi dalam memberikan tambahan pengetahuan kepada masyarakat mengenai perpajakan serta mengevaluasi kebijakan pengampunan pajak yang telah dilakukan oleh pemerintah. Penelitian ini disajikan dalam lima bagian, yaitu pendahuluan, tinjauan literatur dan pengembangan hipotesis, metode penelitian, hasil penelitian dan pembahasan, serta simpulan dan saran.

\section{Tinjauan Literatur dan Pengembangan Hipotesis}

Penelitian ini dikembangkan dengan menggunakan tiga teori, yaitu teori atribusi, teori kontrak pajak psikologis, dan teori keadilan.

\section{Teori Atribusi}

Teori atribusi menyatakan bahwa individuindividu mengamati perilaku seseorang dan mereka mencoba menentukan apakah perilaku tersebut timbul secara internal atau eksternal (Robbins, 1996). Perilaku yang timbul secara internal adalah perilaku yang berada di bawah kendali pribadi individu tersebut. Perilaku yang timbul secara eksternal adalah perilaku yang dipengaruhi keadaan di luar diri individu. Teori atribusi berkaitan dengan variabel moral pajak dan sanksi pajak. Moral pajak merupakan motivasi yang timbul dari dalam diri individu untuk menunaikan kewajiban perpajakannya. Sanksi pajak merupakan dorongan yang berasal dari luar diri individu untuk membayar kewajiban perpajakannya. Dengan kata lain, individu terpaksa untuk melakukan suatu hal karena didorong oleh situasi (Jatmiko, 2006).

\section{Teori Kontrak Pajak Psikologis}

Kepatuhan pajak didorong oleh kontrak pajak psikologis antara masyarakat dan otoritas pajak (Feld dan Frey, 2002). Dalam kontrak psikologis, diperlukan adanya penghargaan dan sanksi. Selain itu, diperlukan juga loyalitas dan emosi yang melandasi. Feld dan Frey (2002) menyebutkan bahwa terdapat hubungan antara pembayar pajak dan otoritas pajak yang saling menghormati dan jujur. Apabila pembayar pajak diperlakukan dengan kurang baik, maka kontrak pajak psikologis telah dilanggar. Hal tersebut membuat masyarakat memiliki sebuah alasan untuk tidak mematuhi kontrak yang ada, artinya mereka memilih untuk tidak melakukan kewajiban pajaknya. Teori ini dapat menjelaskan variabel moral pajak dan kebijakan pengampunan pajak. Teori kontrak pajak menjelaskan variabel moral pajak melalui pengukuran kepercayaan terhadap pemerintah. Di sisi lain, adanya kebijakan pengampunan pajak dianggap melanggar kontrak psikologis antara pemerintah dengan wajib pajak karena memberikan pengampunan terhadap pelanggaran pajak.

\section{Teori Keadilan}

Teori keadilan menyatakan bahwa individu yang merasa dirinya sebagai orang yang terlalu tidak diuntungkan atau merasa sangat diuntungkan akan mengalami kesusahan, dan kesusahan tersebut membawa pada usaha untuk mengembalikan keadilan. Adams dalam Huseman, Hatfield, dan Miles (1987) menyampaikan bahwa teori keadilan dibentuk dari teori pertukaran, disonansi, dan perbandingan sosial dalam membentuk prediksi mengenai bagaimana individu mengatur hubungan mereka dengan orang lain. Teori keadilan berkaitan dengan pengukuran keadilan perpajakan yang merupakan bagian dari pengukuran variabel moral pajak. Hasil penggunaan uang pajak tidak hanya diperuntukkan oleh wajib pajak saja, tetapi oleh 
semua masyarakat di Indonesia, bahkan orang yang lalai dalam membayar pajak.

\section{Penelitian Terdahulu}

Trivedi, Shehata, dan Lynn (2003) meneliti tentang faktor situasional dan faktor personal yang mempengaruhi kepatuhan pajak di Kanada. Penelitian ini bertujuan untuk menguji dan menganalisis dampak dari tiga faktor personal (pertimbangan moral, orientasi nilai, dan preferensi risiko) dan tiga faktor situasional (ada atau tidak adanya audit, ketidakadilan pajak, dan tingkah laku peer-reporting), sembari mengendalikan dampak karakteristik demografis pada kepatuhan pajak. Hasil penelitian menunjukkan bahwa audit, peer reporting, dan keadilan pajak serta variabel personal dan demografis secara statistik signifikan dalam menjelaskan kepatuhan pajak.

Torgler (2004) menganalisis mengenai dampak kepercayaan pada negara dan korupsi pada moral pajak. Hasil penelitian tersebut menunjukkan bahwa kepercayaan seseorang terhadap sistem hukum, keadilan, serta pemerintah memiliki dampak positif signifikan terhadap kepatuhan pajak. Tingkat korupsi juga berpengaruh positif signifikan, artinya pemerintahan yang transparan dapat meningkatkan moral pajak. Cyan, Koumpias, dan MartinezVazquez (2016) juga meneliti pengaruh dari umur, jenis kelamin, pendidikan, dan status pekerjaan terhadap moral pajak. Hasilnya menunjukkan bahwa kelompok yang partisipasi kerjanya lebih rendah, lebih berpendidikan, dan perempuan memiliki moral pajak yang lebih tinggi.

Saracoglu dan Caskurlu (2011) meneliti mengenai pengampunan pajak yang dihubungkan dengan kepatuhan pajak, audit pajak, dan dorongan dari pemerintah. Penelitian ini didorong oleh pengulangan dalam pengampunan pajak di Turki yang tinggi serta sanksi pajak yang tingkatnya dari denda sampai dengan penjara. Hasil penelitian ini menyatakan bahwa para pembayar pajak yang jujur mulai melihat bahwa pengampunan pajak sebagai penghargaan pada pengemplang pajak dan menjadi kondisi yang membahayakan kepatuhan mereka. Ketika mempertimbangkan frekuensi pengampunan pajak di Turki, disimpulkan bahwa pengampunan pajak efektif untuk pembayar pajak langsung untuk tidak melaporkan kegiatannya dan mempersulit kepatuhan pajak.

Rahman (2017) melakukan penelitian tentang permasalahan rendahnya kepatuhan perpajakan di Indonesia. Penelitian tersebut dilakukan kepada petugas pajak, dalam perannya sebagai pelayan publik atau pembayar pajak. Penelitian ini menggunakan beberapa faktor yang mempengaruhi kepatuhan pajak, diantaranya sistem administrasi pajak yang modern, sanksi pajak, pelayanan pajak, dan moral pajak. Hasil penelitian menemukan bahwa sistem administrasi pajak yang modern, pelayanan pajak, dan moral pajak berhubungan secara positif terhadap kepatuhan pajak.

Wirawan dan Noviari (2017) meneliti mengenai pengaruh penerapan kebijakan pengampunan pajak dan sanksi perpajakan terhadap kepatuhan Wajib Pajak Orang Pribadi di KPP Pratama Denpasar Timur. Penelitian ini menemukan bahwa amnesti pajak memiliki pengaruh positif dan signifikan terhadap kepatuhan pajak. Apabila amnesti pajak mengalami peningkatan, maka kepatuhan pajak akan meningkat juga. Sanksi perpajakan berpengaruh positif dan signifikan terhadap kepatuhan wajib pajak.

\section{Pengembangan Hipotesis}

Moral pajak merupakan motivasi yang timbul secara intrinsik untuk membayar pajak, yang berasal dari kesadaran bahwa penerimaan pajak berkontribusi untuk menyediakan barang publik (Cummings et al., 2009). Moral pajak juga dapat dijelaskan dengan menggunakan teori kontrak pajak psikologis. Adanya ikatan antara pembayar pajak dan negara merepresentasikan inti dari moral pajak individu, dan kemudian secara positif dapat berpengaruh terhadap kepatuhan (Feld dan Frey, 2007).

Lebih lanjut, Feld dan Frey (2007) menyampaikan bahwa moral pajak seseorang lebih tinggi apabila mereka memiliki kepercayaan yang tinggi terhadap pemerintah atau sistem hukum yang berlaku. Penelitian menyatakan bahwa terdapat pengaruh positif antara moral pajak dengan kepatuhan pajak (Torgler, 2004; Rahman, 2017). Cyan, Koumpias, dan Martinez-Vazquez (2016) mengungkapkan bahwa kelompok yang partisipasi kerjanya lebih rendah, lebih berpendidikan, dan perempuan memiliki moral pajak yang lebih tinggi.

\section{H1: Moral pajak berpengaruh secara positif terhadap kepatuhan wajib pajak.}

Sanksi pajak merupakan cara yang efektif untuk mencegah terjadinya ketidakpatuhan pajak apabila dilakukan dengan tegas. Teori atribusi menyatakan bahwa apabila individu mengamati perilaku seseorang, maka mereka sedang mencoba untuk menemukan apakah perilaku tersebut didorong secara internal atau eksternal. Kaitan antara teori atribusi dan kepatuhan pajak terdapat pada adanya dorongan yang berasal dari luar diri individu, yaitu sanksi pajak yang mendorong mereka untuk memenuhi kewajibannya membayar pajak. Trivedi, Shehata, dan Lynn (2003) menyatakan bahwa sanksi pajak merupakan motivasi yang besar bagi seseorang untuk membayar pajak. Penelitian yang dilakukan oleh Jatmiko (2006), Mutia (2014), dan Wirawan dan Noviari (2017) menemukan bahwa sanksi perpajakan berpengaruh positif terhadap kepatuhan wajib pajak orang pribadi. 


\section{H2: Sanksi pajak berpengaruh secara positif} terhadap kepatuhan wajib pajak.

Kebijakan pengampunan pajak telah dilaksanakan tiga kali di Indonesia, yaitu pada tahun 1984, 2007, dan 2016. Penelitian yang dilakukan oleh Wirawan dan Noviari (2017) menemukan bahwa pengampunan pajak berpengaruh secara positif terhadap kepatuhan wajib pajak. Ia menyatakan bahwa pemerintah mengeluarkan kebijakan pengampunan pajak dengan harapan dapat meningkatkan kepatuhan pajak sehingga pendapatan negara meningkat.

Di sisi lain, Rechberger (2010) menyatakan bahwa kebijakan pengampunan pajak dapat dipandang dari segi teori kontrak psikologis. Adanya kebijakan pengampunan pajak dianggap telah melanggar adanya kontrak psikologis antara wajib pajak dengan pemerintah dan otoritas pajak. Kontrak psikologis dapat terjaga apabila wajib pajak membayar kewajiban pajaknya dengan jujur. Apabila dipandang dari segi pemerintah, kontrak psikologis terjaga apabila pemerintah dapat menghormati wajib pajak dan mencegah adanya eksploitasi terhadap wajib pajak yang telah jujur (Rechberger, 2010).

\section{H3: Kebijakan pengampunan pajak berpengaruh secara positif terhadap kepatuhan wajib pajak.}

\section{Metode Penelitian}

\section{Desain Penelitian}

Penelitian ini dilakukan dengan dengan metode kuantitatif. Teknik pengumpulan data penelitian ini dilakukan dengan survei dengan menyebarkan kuesioner kepada wajib pajak orang pribadi yang berada di wilayah Daerah Istimewa Yogyakarta.

\section{Populasi dan Sampel}

Populasi penelitian adalah wajib pajak orang pribadi (WPOP) yang telah memiliki nomor pokok wajib pajak (NPWP) yang terdaftar di Kantor Pelayanan Pajak yang terdapat di wilayah Daerah Istimewa Yogyakarta. Metode pengambilan sampel yang digunakan dalam pengambilan sampel adalah metode convenience.

\section{Definisi dan Pengukuran Variabel}

\section{Kepatuhan Pajak}

Rahman (2017) mendefinisikan kepatuhan pajak sebagai kepatuhan pembayar pajak terhadap hukum perpajakan yang berlaku, dimana terdiri atas aktivitas seperti mendaftarkan diri sebagai pembayar pajak, mengisi formulir pajak dengan jelas dan lengkap, menghitung secara benar jumlah pajak yang terutang, membayar pajak yang terutang dengan tepat waktu, semuanya dilakukan dengan sukarela, tanpa investigasi, peringatan, ancaman, atau memberikan sanksi administratif maupun kriminal sebelumnya. Kepatuhan pajak dalam penelitian diukur dengan lima item pernyataan yang digunakan oleh Mohdali dan Pope (2012).

\section{Moral Pajak}

Torgler dalam Cyan, Koumpias, dan MartinezVazquez (2016) mendefinisikan moral pajak sebagai kesediaan untuk mematuhi kewajiban pajak. Moral pajak meliputi prinsip, norma, dan nilai yang dipegang oleh individu dalam menyadari kewajiban perpajakan mereka (Rahman, 2017). Pengukuran yang digunakan dalam proksi moral pajak menggunakan pengukuran yang dikembangkan oleh Rahman (2017). Pengukuran tersebut terdiri atas pengetahuan perpajakan, keadilan pajak, dan kepercayaan terhadap pemerintah.

\section{Sanksi Pajak}

Mutia (2014) menyatakan bahwa pengenaan sanksi pajak terhadap wajib pajak dapat menyebabkan terpenuhinya kewajiban perpajakan sehingga dapat meningkatkan kepatuhan pajak wajib pajak itu sendiri. Variabel sanksi pajak diukur dengan item pertanyaan yang dikembangkan oleh Rahman (2017).

\section{Kebijakan Pengampunan Pajak}

Undang-Undang Nomor 11 Tahun 2016 tentang Pengampunan Pajak mendefinisikan pengampunan pajak sebagai penghapusan pajak yang seharusnya terutang, tidak dikenai sanksi administrasi perpajakan dan sanksi pidana di bidang perpajakan, dengan cara mengungkap Harta dan membayar Uang Tebusan sebagaimana diatur dalam Undang-Undang tersebut. Variabel pengampunan pajak diukur dengan item pertanyaan yang dikembangkan oleh Saracoglu dan Caskurlu (2011).

\section{Variabel Kontrol}

Variabel kontrol atau variabel pengendali adalah variabel yang dimasukkan untuk membantu menafsirkan hubungan antar variabel (Cooper dan Schindler, 2006). Variabel kontrol dalam penelitian ini terdiri atas empat variabel, yaitu jenis kelamin, penghasilan, umur, dan tingkat pendidikan seperti yang digunakan oleh Engida dan Baisa (2014).

\section{Uji Hipotesis}

Hipotesis penelitian ini diuji dengan menggunakan regresi berganda. Metode ini dipilih karena analisis regresi tidak hanya mengukur kekuatan hubungan antara dua variabel atau lebih, namun juga menunjukkan arah hubungan antara variabel dependen dengan variabel independen (Ghozali, 2009). Model analisis regresi yang digunakan dalam penelitian ini adalah:

$$
\begin{gathered}
\mathrm{Y}=\mathrm{a}+\mathrm{b}_{1} \mathrm{X}_{\mathrm{MP}}+\mathrm{b}_{2} \mathrm{X}_{\mathrm{SP}}+\mathrm{b}_{3} \mathrm{X}_{\mathrm{KPP}}+\mathrm{b}_{3} \mathrm{KJK}+\mathrm{b}_{4} \mathrm{KP}+ \\
\mathrm{b}_{5} \mathrm{KU}-\mathrm{b}_{6} \mathrm{KTP}+e \ldots \ldots \ldots \ldots \ldots . .1(1)
\end{gathered}
$$


Keterangan:

$\mathrm{Y} \quad=$ Kepatuhan pajak wajib pajak orang pribadi

$$
\begin{array}{ll}
\mathrm{MP} & =\text { Moral pajak } \\
\mathrm{SP} & =\text { Sanksi pajak } \\
\mathrm{KPP} & =\text { Kebijakan pengampunan pajak } \\
\mathrm{KJK} & =\text { Variabel kontrol jenis kelamin } \\
\mathrm{KP} & =\text { Variabel kontrol penghasilan } \\
\mathrm{KU} & =\text { Variabel kontrol umur } \\
\mathrm{KTP} & =\text { Variabel kontrol tingkat pendidikan } \\
e & =\text { error }
\end{array}
$$

\section{Hasil Penelitian dan Pembahasan}

\section{Gambaran Data Penelitian}

Data penelitian ini dikumpulkan melalui penyebaran kuesioner baik secara langsung maupun secara online. Penyebaran kuesioner secara langsung dilakukan dengan mendatangi responden secara langsung serta mengikuti acara yang dilakukan oleh perkumpulan wirausaha di Daerah Istimewa Yogyakarta. Jumlah kuesioner yang disebar sebanyak 180 kuesioner, dan kuesioner yang diterima kembali sebanyak 123. Kuesioner yang dapat digunakan untuk penelitian ini sebanyak 106 kuesioner.

TABEL 1

KARAKTERISTIK RESPONDEN

\begin{tabular}{lll}
\hline Karakteristik & Keterangan & Jumlah \\
\hline Jenis kelamin & Pria & 47 \\
& Wanita & 59 \\
Umur & $20-29$ & 52 \\
& $30-39$ & 25 \\
& $40-49$ & 15 \\
& $\geq 50$ & 14 \\
Pendidikan & SMP/ SMA & 21 \\
& Diploma & 6 \\
& S1 & 58 \\
& S2 & 20 \\
& S3 & 1 \\
& $\leq 3.000 .000$ & 40 \\
& $3.000 .001-$ &
\end{tabular}

$\begin{array}{ll}6.000 .000 & 41 \\ 6.000 .001- & 16 \\ 9.000 .000 & \\ >9.000 .000 & 9\end{array}$

Pekerjaan PNS 5

Karyawan 31

Wiraswasta $\quad 37$

Mahasiswa 7

Lainnya 26

Pernah Pernah 13

$\begin{array}{ll}\text { mengikuti } & \text { Belum pernah } 93\end{array}$

pengampunan

pajak

$\begin{array}{lll}\begin{array}{l}\text { Cara } \\ \text { menghitung } \\ \text { pajak }\end{array} & \text { Sendiri } & 96 \\ & \text { Orang lain } & 10\end{array}$

Responden penelitian ini terdiri atas 47 responden pria dan 59 responden wanita. Berdasarkan karakteristik umur, responden yang berumur antara 20-29 tahun terdapat 52 orang, responden yang berumur antara 30-39 tahun terdapat 25 orang, responden yang berumur 40-49 tahun terdapat 15 orang, serta responden yang berumur lebih dari atau sama dengan 50 tahun terdapat sebanyak 14 responden.

Berdasarkan karakteristik pendidikan, responden yang berpendidikan SMP atau SMA terdiri atas 21 orang. Responden yang berpendidikan diploma terdiri atas 6 orang. Responden yang berpendidikan strata 1 terdiri atas 58 orang. Responden yang berpendidikan strata 2 terdapat sebanyak 20 orang. Responden yang berpendidikan strata 3 sebanyak 1 orang.

Berdasarkan karakteristik penghasilan dikategorikan menjadi empat kategori. Responden yang berpenghasilan kurang dari atau sama dengan Rp3.000.000,00 terdiri atas 40 orang, responden yang berpenghasilan Rp3.000.001,00 sampai dengan Rp6.000.000,00 terdiri atas 41 orang, responden yang berpenghasilan Rp6.000.001,00 sampai dengan Rp9.000.000,00 terdiri atas 16 orang, dan responden yang berpenghasilan lebih dari Rp9.000.000,00 terdapat sebanyak 9 orang. Berdasarkan karakteristik pernah mengikuti kebijakan pengampunan pajak, sebanyak 13 orang dari 106 orang menjawab sudah pernah mengikuti kebijakan tersebut. 


\section{Uji Pilot}

Uji pilot dilakukan pada 30 mahasiswa akuntansi Universitas Gadjah Mada yang telah mengambil mata kuliah perpajakan. Hasil pengujian realibilitas dapat dilihat dari nilai Cronbach's alpha, sedangkan pengujian validitas dapat dilihat dari nilai Corrected Item-Total Correlation.

Suatu instrumen dikatakan reliabel apabila memiliki nilai Cronbach's alpha lebih besar dari 0,70 (Ghozali, 2009). Pada pengujian reliabilitas, variabel kepatuhan pajak memiliki nilai Cronbach's alpha 0,772 , variabel moral pajak memiliki nilai Cronbach's alpha 0,805, variabel sanksi pajak memiliki nilai Cronbach's alpha 0,876, serta variabel kebijakan pengampunan pajak memiliki nilai Cronbach's alpha 0,728. Hasil pengujian keempat variabel tersebut dapat memberikan bukti bahwa keempat variabel yang digunakan reliabel.

Pada pengujian validitas instrumen, apabila $r_{\text {hitung }}>r_{\text {tabel }}$ maka dapat dikatakan valid. Besarnya $\mathrm{r}_{\text {tabel }}$ untuk $\mathrm{n}=30$ adalah 0,361 , artinya setiap item indikator harus memiliki $\mathrm{r}_{\text {hitung }}$ lebih dari 0,361 . Variabel kepatuhan pajak diukur dengan menggunakan lima indikator. Hasil pengujian validitas menunjukkan bahwa kelima indikator tersebut memiliki $\mathrm{r}_{\text {hitung }}$ lebih besar dari 0,361.

Variabel moral pajak terdiri atas delapan indikator. Dari kedelapan indikator tersebut, secara keseluruhan memiliki $r_{\text {hitung }}$ lebih besar dari 0,361 . Variabel sanksi pajak diukur dengan enam indikator. Keenam indikator yang digunakan untuk mengukur variabel sanksi pajak memiliki nilai lebih dari 0,361. Variabel kebijakan pengampunan pajak terdiri atas tiga indikator, dimana seluruhnya memiliki nilai lebih dari 0,361. Artinya, seluruh indikator yang digunakan untuk mengukur variabel kepatuhan pajak, moral pajak, sanksi pajak, dan kebijakan pengampunan pajak valid.

\section{Uji Asumsi Klasik}

Uji normalitas dilakukan untuk memastikan bahwa populasi residual berdistribusi normal. Pada penelitian ini, uji normalitas dilakukan dengan Kolmogorov-Smirnov. Nilai signifikansi yang diperoleh adalah 0,061 . Nilai tersebut telah melebihi 0,05 yang menunjukkan bahwa data yang digunakan dalam penelitian ini telah berdistribusi normal. Di samping itu, hasil pengujian multikolinearitas menunjukkan bahwa semua variabel yang digunakan dalam penelitian ini memiliki nilai VIF $<10$ serta nilai tolerance $>0,1$. Hal ini menunjukkan bahwa tidak ada hubungan linier antara seluruh variabel yang digunakan dalam penelitian ini dengan model regresinya. Berdasarkan hasil uji heteroskedastisitas yang dilakukan, menunjukkan bahwa ketujuh variabel mulai dari variabel moral pajak hingga tingkat penghasilan memiliki nilai signifikansi lebih dari 0,05 . Hal ini menunjukkan bahwa dalam model penelitian ini tidak ditemukan adanya gejala heteroskedastisitas.

\section{Analisis Regresi Berganda}

Setelah melakukan uji asumsi klasik, dilakukan analisis regresi berganda dengan menggunakan SPSS versi 23. Berikut merupakan hasil analisis regresi berganda, uji koefisien determinasi, dan uji $\mathrm{F}$ yang telah dilakukan:

TABEL 2

HASIL UJI REGRESI BERGANDA, UJI KOEFISIEN DETERMINASI, DAN UJI F

\begin{tabular}{lccc}
\multicolumn{4}{c}{ DAN UJI F } \\
\hline Variabel & Koefisien & $\mathrm{t}$ & Sig. \\
\hline Konstanta & 1,803 & 4,123 & 0,000 \\
Moral Pajak & 0,354 & 3,176 & $0,002^{*}$ \\
Sanksi Pajak & 0,113 & 1,361 & 0,177 \\
Amnesti Pajak & 0,159 & 2,201 & $0,030^{*}$ \\
Jenis Kelamin & $-0,046$ & $-0,447$ & 0,656 \\
Umur & $-0,014$ & $-0,298$ & 0,766 \\
Pendidikan & 0,079 & 1,429 & 0,156 \\
Tingkat & 0,039 & 0,668 & 0,506 \\
Penghasilan & & & \\
Adjusted $R$ Square $=0,203$ & & \\
$F$ statistics =0,000* & & \\
\hline *menunjukkan bahwa koefisien variabel signifikan \\
pada level 0,05
\end{tabular}

Berdasarkan Tabel 1, dapat dirumuskan persamaan regresi yang digunakan dalam penelitian ini sebagai berikut:

$$
\begin{gathered}
\mathrm{Y}=1,803+0,354 \mathrm{X}_{\mathrm{MP}}+0,113 \mathrm{X}_{\mathrm{SP}}+0,159 \mathrm{X}_{\mathrm{KPP}}- \\
0,046 \mathrm{KJK}-0,014 \mathrm{KP}+0,079 \mathrm{KU}+0,039 \mathrm{KTP}+e
\end{gathered}
$$

\section{Uji Koefisien Determinasi}

Pengujian koefisien determinasi $\left(\mathrm{R}^{2}\right)$ mengukur seberapa jauh kemampuan model dalam menerangkan variasi variabel dependen (Ghozali, 2009). Nilai koefisien determinasi adalah antara nol dan satu. Semakin besar nilai $\mathrm{R}^{2}$, maka semakin bagus model regresi yang digunakan.

Tabel 1 menunjukkan hasil pengujian koefisien determinasi yang menunjukkan angka 0,203. Hal ini mengimplikasikan bahwa variabilitas variabel terikat yang dapat dijelaskan oleh variabilitas variabel bebas dan variabel kontrol sebesar 20,3 persen. Artinya, terdapat sebanyak 79,7 persen dijelaskan oleh variabel lain yang tidak dimasukkan dalam model regresi.

\section{Uji Statistik F}

Pengujian statistik $F$ atau uji ANOVA dilakukan untuk melihat apakah variabel independen yang dimasukkan ke dalam model regresi secara keseluruhan memiliki pengaruh secara bersamasama terhadap variabel dependen. Hal ini dapat diketahui dari hasil $F_{\text {hitung }}$ yang terdapat pada tabel ANOVA yang kemudian dibandingkan dengan nilai $F_{\text {tabel }}$ pada df $1=7$ dan df $2=98 . F_{\text {tabel }}$ ANOVA untuk df $1=7$ dan df 2=98 menunjukkan angka 2,10. Hasil pengujian $F$ menunjukkan $F_{\text {hitung }}$ sebesar 4,825 . Nilai 
$F_{\text {hitung }}$ tersebut lebih besar dari nilai $F_{\text {tabel }}$ yang bernilai 2,10. Nilai signifikansi yang diperoleh adalah sebesar 0,000 yang lebih kecil dari 0,05. Oleh karena itu dapat disimpulkan bahwa seluruh variabel bebas dan variabel kontrol secara bersama-sama mempengaruhi variabel terikat.

\section{Uji Statistik t}

Pengujian dilakukan dengan membandingkan antara $t_{\text {hitung }}$ dengan $t_{\text {tabel }}$ pada signifikansi $5 \%$ dan df 106 yaitu sebesar 1,65. Berdasarkan Tabel 1, pengujian hipotesis 1 menghasilkan $t_{\text {hitung }}$ sebesar 3,176 dan signifikansi sebesar 0,002. Apabila $t_{\text {hitung }}$ moral pajak $>t_{\text {tabel }}$ serta nilai signifikansi $<0,05$ menandakan bahwa variabel moral pajak berpengaruh positif dan signifikan terhadap kepatuhan pajak. Berdasarkan hasil tersebut, maka hipotesis 1 penelitian ini terdukung.

Pengujian hipotesis 2 menghasilkan $t_{\text {hitung }}$ sebesar 1,361 dan signifikansi sebesar 0,177. Hasil ini menunjukkan bahwa $t_{\text {hitung }}$ sanksi pajak $<\mathrm{t}_{\text {tabel }}$ serta nilai signifikansi $>0,05$. Hasil tersebut menandakan bahwa variabel sanksi pajak berpengaruh positif dan tidak signifikan terhadap kepatuhan pajak. Berdasarkan hasil tersebut, maka hipotesis 2 penelitian ini tidak terdukung.

Pengujian hipotesis 3 menghasilkan $t_{\text {hitung }}$ sebesar 2,201 dan signifikansi sebesar 0,030. Apabila $t_{\text {hitung }}$ kebijakan pengampunan pajak $>t_{\text {tabel }}$ serta nilai signifikansi $<0,05$ menandakan bahwa variabel kebijakan pengampunan pajak berpengaruh positif dan signifikan terhadap kepatuhan pajak. Berdasarkan hasil tersebut, maka hipotesis 3 penelitian ini terdukung.

Pengujian yang dilakukan pada variabel kontrol menunjukkan bahwa variabel jenis kelamin menghasilkan $t_{\text {hitung }}$ sebesar -0,447 dan signifikansi sebesar 0,656; variabel umur menghasilkan $t_{\text {hitung }}$ sebesar -0,298 dan signifikansi sebesar 0,766; variabel pendidikan menghasilkan $t_{\text {hitung }}$ sebesar 1,429 dan signifikansi sebesar 0,156 ; serta variabel tingkat penghasilan menghasilkan $t_{\text {hitung }}$ sebesar 0,668 dan signifikansi sebesar 0,506. Secara keseluruhan, $t_{\text {hitung }}$ variabel kontrol $<\mathrm{t}_{\text {tabel }}$ serta nilai signifikansi > 0,05 menandakan bahwa variabel kontrol tersebut tidak berpengaruh secara signifikan terhadap kepatuhan pajak.

\section{Pembahasan Hipotesis dan Variabel Kontrol}

\section{Moral Pajak}

Berdasarkan Tabel 1, hasil pengujian $t$ menunjukkan nilai $t_{\text {hitung }}$ sebesar 3,176 dan signifikansi sebesar 0,002 . Hal ini berarti bahwa variabel moral pajak berpengaruh secara positif dan signifikan terhadap kepatuhan pajak. Hasil penelitian ini mendukung hasil penelitian sebelumnya yang dilakukan oleh Torgler (2004) serta Rahman (2017). Hasil tersebut menunjukkan bahwa wajib pajak di Daerah Istimewa Yogyakarta memiliki motivasi yang berasal dari dalam dirinya serta memiliki kesadaran bahwa pajak yang mereka bayarkan merupakan kontribusi mereka pada negara untuk menyediakan barang publik.

Apabila dijelaskan dengan menggunakan teori keadilan, Wajib pajak di Daerah Istimewa Yogyakarta merasa bahwa pemerintah telah memberikan pelayanan serta fasilitas yang sebanding dengan apa yang diberikan oleh masyarakat melalui pajak. Masyarakat merasa bahwa penggunaan uang pajak telah memuaskan kedua pihak, baik masyarakat maupun negara. masyarakat telah mempercayai pemerintah dalam mengelola uang pajak yang mereka bayarkan untuk melaksanakan pembangunan dengan baik dan tidak menyalahgunakan uang pajak untuk korupsi.

\section{Sanksi Pajak}

Berdasarkan Tabel 1, hasil pengujian yang dilakukan pada variabel sanksi pajak memperoleh $t_{\text {hitung }}$ sebesar 1,361 yang kurang dari nilai $t_{\text {tabel }} 1,65$ serta tingkat signifikansi sebesar 0,177 yang lebih dari 0,05 . Hal ini menunjukkan bahwa sanksi pajak berpengaruh positif dan tidak signifikan terhadap kepatuhan pajak wajib pajak. Hasil penelitian ini mendukung hasil penelitian sebelumnya yang dilakukan oleh Engida dan Baisa (2014) serta Winerungan (2013) yang menyatakan bahwa tingkat kesadaran wajib pajak terhadap adanya sanksi pajak masih relatif rendah dan cenderung mengabaikannya. Masyarakat masih memandang pelaksanaan sanksi pajak yang masih lemah serta sosialisasi peraturan dan sanksi pajak yang belum optimal menyebabkan pemahaman masyarakat terhadap sanksi pajak masih rendah. Hal tersebut yang mendorong wajib pajak masih belum mematuhi peraturan dan melaksanakan kewajiban perpajakannya dengan baik.

Masyarakat memandang pemerintah belum konsisten dalam melaksanakan sanksi perpajakan yang berlaku (Ragimun, 2014). Kondisi ini juga didukung oleh adanya pelaksanaan kebijakan pengampunan pajak oleh pemerintah pada tahuntahun yang lalu. Lebih lanjut, Ragimun (2014) menyatakan bahwa kebijakan pengampunan pajak yang dilakukan oleh pemerintah juga mendorong masyarakat untuk tidak takut terhadap sanksi pajak.

\section{Kebijakan Pengampunan Pajak}

Hasil pengujian statistik t yang dilakukan pada hipotesis ketiga penelitian ini memperoleh $t$ hitung 3,176 serta nilai signifikansi sebesar 0,002. Hal ini berarti bahwa kebijakan pengampunan pajak berpengaruh positif dan signifikan terhadap kepatuhan perpajakan. Artinya, adanya kebijakan pengampunan pajak dapat meningkatkan kepatuhan pajak wajib pajak.

Hipotesis ketiga yang diajukan dalam penelitian ini terdukung. Hasil ini sesuai dengan 
hasil penelitian sebelumnya yang telah dilakukan oleh Wirawan dan Noviari (2017). Penelitian tersebut juga menemukan bahwa kebijakan pengampunan pajak berpengaruh secara positif terhadap kepatuhan pajak. Wirawan dan Noviari (2017) menyatakan bahwa pemerintah melakukan kebijakan pengampunan pajak dalam rangka meningkatkan kesejahteraan masyarakat melalui uang pajak yang diperoleh.

Adanya kebijakan pengampunan pajak dipandang oleh para wajib pajak sebagai sebuah kebijakan yang baik. Hal ini dikarenakan pemerintah memberikan kesempatan kepada warganya untuk dapat lebih jujur dengan mengampuni pelanggaran yang dilakukan. Pelaksanaan kebijakan ini membuat para wajib pajak menggunakan momentum tersebut untuk memperbaiki data pajak yang belum disampaikan, karena pemerintah tidak mengenakan denda bagi wajib pajak yang belum melaporkan asetnya.

\section{Variabel Kontrol}

Pengujian yang dilakukan pada variabel kontrol menunjukkan hasil yang tidak signifikan. Jenis kelamin tidak dapat digunakan dalam menentukan kepatuhan pajak seseorang (Richardson, 2006). Pada variabel kontrol umur, Wahlund (1992) menyatakan bahwa orang yang berusia lebih tua lebih tidak patuh terhadap pajak. Hal ini dapat terjadi karena seseorang yang berusia tua lebih sibuk dan tidak mengetahui informasi perpajakan yang baru sehingga kurang patuh dalam perpajakan.

Hasil variabel kontrol pendidikan yang tidak berpengaruh secara signifikan mendukung hasil penelitian sebelumnya yang dilakukan oleh Chan, Troutman, dan O'Bryan (2000) yang menyatakan bahwa wajib pajak yang berpendidikan akan memiliki pengetahuan yang lebih banyak untuk dapat melanggar peraturan pajak. Variabel kontrol tingkat pendidikan yang tidak signifikan dikarenakan adanya tingkat pajak progresif yang mendorong kelompok dengan penghasilan tinggi untuk menghindari kewajiban pajaknya (Engida dan Baisa, 2014).

\section{Simpulan dan Saran}

Berdasarkan pemaparan yang telah dijelaskan sebelumnya, maka dapat disimpulkan:

1. Variabel moral pajak memperlihatkan pengaruh yang positif dan signifikan terhadap kepatuhan pajak wajib pajak orang pribadi di Daerah Istimewa Yogyakarta. Hal ini menunjukkan bahwa moral pajak seseorang dapat meningkatkan kepatuhan dalam melaksanakan kewajiban pajak.

2. Variabel sanksi pajak menunjukkan pengaruh yang positif dan tidak signifikan. Hal ini diduga karena adanya pelaksanaan sanksi pajak yang belum tegas serta kebijakan pengampunan pajak yang membuat mereka merasa bahwa di masa yang akan datang kebijakan tersebut akan diadakan kembali. Hal ini membuat masyarakat menjadi tidak takut terhadap sanksi pajak dan enggan untuk patuh terhadap peraturan perpajakan.

3. Variabel kebijakan pengampunan pajak menunjukkan pengaruh yang positif dan signifikan. Hasil ini memperlihatkan bahwa adanya kebijakan pengampunan pajak dapat meningkatkan kepatuhan pajak wajib pajak orang pribadi di Daerah Istimewa Yogyakarta. Masyarakat menganggap adanya kebijakan tersebut dapat mendorong mereka untuk menjadi lebih patuh karena pelanggaran pajak yang mereka lakukan di masa lalu telah diampuni oleh negara, sehingga mereka tidak perlu membayar denda ataupun mendapatkan sanksi yang berat.

Penelitian ini memiliki beberapa kelemahan. Pertama, diperlukan kehati-hatian dalam melakukan generalisasi hasil. Kedua, pengukuran moral pajak yang hanya dipadang melalui tingkat pengetahuan, persepsi terhadap pemerintahan, serta persepsi terhadap keadilan pajak. Ketiga, penelitian ini dilakukan pada saat setelah diberlakukannya kebijakan pengampunan pajak, sehingga tidak diketahui bagaimana perbedaan antara sebelum pelaksanaan dan setelah pelaksanaan kebijakan.

Penelitian selanjutnya diharapkan dapat meneliti dalam cakupan wilayah yang lebih besar agar dapat meningkatkan kemampuan generalisasi. Selain itu, penelitian selanjutnya dapat mengembangkan pengukuran dari variabel moral pajak dengan pengukuran yang lebih lengkap. Pengukuran yang lebih lengkap dapat dilakukan dengan menambahkan indikator lain. Penelitian selanjutnya diharapkan lebih lengkap dengan menambahkan analisis yang membandingkan keadaan sebelum dilakukannya kebijakan pengampunan pajak dengan keadaan setelah dilakukannya kebijakan pengampunan pajak.

\section{Daftar Pustaka}

A. Chan. C. W., C. T. Troutman, dan D. O' Bryan. 2000. An expanded model of taxpayer compliance: Empirical evidence from United States and Hong Kong. Journal of International Accounting, Auditing, and Taxation, Vol. 9, pp. 83-103.

B. Cooper, D., dan P. Schindler. 2006. Metode Riset Bisnis Vol. 1 dan 2. McGrawHill: New York.

C. Cummings, R.G., J. Martinez-Vazquez, M. McKee, dan B. Torgler. 2009. Tax morale affects tax compliance: Evidence from surveys and an artefactual field experiment. 
Journal of Economic Behavior \& Organization, Vol. 70, pp. 447-457.

D. Cyan, M. R., A. M. Koumpias, dan J. Martinez-Vazquez. 2016. The determinants of tax morale in Pakistan. Journal of Asian Economics Vol. 47, pp. 23-34.

E. Direktorat Jenderal Pajak. 2017. Statistik Amnesti Pajak. Diakses pada 9 Januari. http://www.pajak.go.id/statistik-amnesti.

F. Engida, T., dan Abera G. B. 2014. Factors Influencing Taxpayers' Compliance with Tax System: An Empirical Study of Mekelle City, Ethiopia. E-Journal of Tax Research. Vol. 12 No. 2, pp. 433-452.

G. Feld, L.P., dan B. S. Frey. 2002. Trust Breed Trust: How Taxpayers are Treated. Economics and Governance. Vol. 3, pp. 87 99.

H. Feld, L.P., dan B. S. Frey. 2007. Tax Compliance as the Result of a Psychological Tax Contract: The Role of Incentives and Responsive Regulation. Law\& Policy Vol. 29 No.1, pp. 102-120.

I. Gerger, G. C. 2012. Tax Amnesties and Tax Compliance in Turkey. International Journal of Multidisciplinary Thought, Vol. 2 No. 3, pp. 107-113.

J. Ghozali, I. 2009. Aplikasi Analisis Multivariate dengan Program IBM SPSS 19. Badan Penerbitan Universitas Diponegoro: Semarang.

K. Huseman, R.C., J. D. Hatfield, dan E. W. Miles. 1987. A New Perspective on Equity Theory: The Equity Sensitivity Construct. The Academy of Management Review, Vol. 12 No. 2, pp. 222-234.

L. Jatmiko, A. N. 2006. Pengaruh Sikap Wajib Pajak pada Pelaksanaan Sanksi Denda, Pelayanan Fiskus dan Kesadaran Perpajakan Terhadap Wajib Pajak. Semarang. Universitas Diponegoro.

M. Kementerian Keuangan Republik Indonesia. 2017. Perekonomian Indonesia dan APBN 2017. Diakses pada 9 Januari 2018. https://www.kemenkeu.go.id/apbn2017

N. Laporan Badan Pusat Statistik 2018.

O. Laporan Kinerja Direktorat Jenderal Pajak 2017.

P. Laporan Kinerja Direktorat Jenderal Pajak 2018.

Q. Mohdali, R., dan J. Pope. 2012. The effect of religiosity and external environment on voluntary tax compliance. New Zealand Journal of Taxation Law and Policy, Vol. 18, pp. 119-139.

R. Mutia, S. P. T. 2014. "Pengaruh Sanksi Perpajakan, Kesadaran Perpajakan, Pelayanan Fiskus, dan Tingkat Pemahaman Terhadap Kepatuhan Wajib Pajak Orang
Pribadi: Studi Empiris pada Wajib Pajak Orang Pribadi yang terdaftar di KPP Pratama Padang." Artikel Ilmiah. Universitas Negeri Padang.

S. Nota Keuangan APBN 2018.

T. Ragimun. 2014. Analisis Implementasi Pengampunan Pajak (Tax Amnesty) di Indonesia. Kementerian Keuangan Republik Indonesia.

U. Rahman, A. 2017. "Tax Compliance in Indonesia, the Role of Public Officials as Taxpayers". Disertasi. University of Twente.

V. Rechberger, S.M.H. 2010. Tax Amnesties, Justice Perceptions, and Filling Behavior. A Simulation Study. Law\& Policy Vol. 32 No.2.

W. Richardson, G. 2006. The impact of tax fairness dimensions on tax compliance behavior in an Asian jurisdiction: The case of Hong Kong. International Tax Journal. Winter, pp. 29-42.

X. Robbins, S.P. 1996. Perilaku Organisasi: Konsep, Kontroversi dan Aplikasi, Edisi Bahasa Indonesia. Prenhallio: Jakarta.

Y. Said, E. W. 2017. Tax Policy in Action: 2016 Tax Amnesty Experience of the Republic of Indonesia. Laws, Vol. 6 No. 16, pp. 1-9.

Z. Saracoglu, O. F. dan E. Caskurlu. 2011. Tax Amnesty with Effects and Effecting Aspects: Tax Compliance, Tax Audits, and Enforcements Around: The Turkish Case. International Journal of Business and Social Science, Vol. 2 No. 7, pp. 95-103.

AA. Suryaningtyas. 2017. "Faktor-faktor yang Memengaruhi Kepatuhan Pajak Berdasarkan Perspektif Pendekatan Psikologis Fiskal". Thesis. Universitas Gadjah Mada.

BB. Torgler, B. 2004. Tax Morale, Trust, and Corruption: Empirical Evidence from Transition Countries. CREMA. Vol. 5.

CC. Trivedi, V. U., M. Shehata, dan B. Lynn. 2003. Impact of Personal and Situational Factors on Taxpayer Compliance: An Experimental Analysis. Journal of Business Ethics, Vol. 47 No.3, pp.175-197.

DD. Undang-Undang No. 17 Tahun 2003 Tentang Keuangan Negara. Presiden Republik Indonesia.

EE. Undang-Undang No. 11 Tahun 2016 Tentang Pengampunan Pajak. Presiden Republik Indonesia.

FF. Wahlund, R. 1992. Tax changes and economic behaviour: The case of tax evasion. Journal of Economic Psychology, Vol. 13, pp. 657-677.

GG. Winerungan, O. L. 2013. Sosialisasi Perpajakan, Pelayanan Fiskus dan Sanksi Perpajakan Terhadap Kepatuhan WPOP di KPP Manado dan KPP Bitung. Jurnal EMBA, Vol. 1 No.3, pp. 960-970. 
HH. Wirawan, I. B. N. A. P., dan N. Noviari. 2017. Pengaruh Penerapan Kebijakan Tax Amnesty dan Sanksi Perpajakan Terhadap
Kepatuhan Wajib Pajak. E-Jurnal Akuntansi Universitas Udayana, Vol. 21 No. 3, pp. 2165-2194. 